ウイルス感染による迷走神経麻痺例

\author{
田浦 晶子・伊藤 壽一・大田 耕造 \\ 藤田 修治・塩見 佳子・雑賀 興慶*
}

\title{
Vagus Nerve Paralysis as a Result of Viral Infection; A Case Report
}

\author{
Akiko Taura, Juichi Ito, Kozo Ota, Shuji Fujita, \\ Yoshiko Shiomi and Toshihiko Saiga \\ (Otsu Red Cross Hospital)
}

\begin{abstract}
A 61-year-old man consulted our hospital, complaining of hoarseness and throat pain. Inspection of the larynx revealed an abnormal mass in the region of the left arytenoid and left laryngeal palsy. Laboratory data revealed slight leukocytosis and an elevation in CRP. Laryngeal carcinoma was suspected based on CTscanning, MRI, esophagography and Ga scintigraphy. Histopathological findings, however, showed only inflammation. A few days after the patient's first visit, left soft palate paralysis and severe hiccups appeared. Jugular foramen syndrome was suspected, but no abnormal mass was detected by MRI. Examination of serum viral titers revealed varicella-zoster virus antibody to be increased by 128 times, and vagal nerve paralysis caused by the varicella-zoster virus was highly suspected. Following therapy, the abnormal mass in the larynx disappeard, but the patient's laryngeal palsy remains.
\end{abstract}

Key words : abnormal mass in the larynx, laryngeal palsy, varicella-zoster virus

はじめに

原因不明の喉頭麻痺症例のなかでウイルス感染を強く 疑う症例は多く存在するものの, 確定診断することは困 難なことが多い，今回，当科で初診時に喉頭腫瘤抽よび 喉頭麻痺を認めたため, 悪性疾患を疑ったものの，最終 的にはウイルスによる迷走神経障害と判明した症例を経 験した．喉頭運動麻痺に他の脳神経麻痺が合併したもの を混合性喉頭麻瘏といらが，そのらちで本症例のように 迷走神経のみの麻疩は約 2 割あるとされている1). しか し，喉頭に腫瘤性病变を認めた症例は今まで報告されて 抢らず，本症例は極めて珍しいと思われるので報告する。
症例

症例 : 61歳, 男性.

主訴 : 咽頭痛, 嗄声.

現病歴: 平成 7 年11月 4 日より発熱, 咽頭痛が出現. 11月 6 日近院受診し, 抗生剂, 鎮痛剂の内服治療を受け ていたが症状軽快せず. 11 月 9 日嗄声が出現したため, 当科受診となる.

既往歴，家族歴：特記すべきことなし.

入院時所見：喉頭所見にて左披裂部に表面平滑な水疱 状腫瘤を認め, 声帯は傍正中位に固定し, 左喉頭麻痺を 認めた(図 1 ).

検查所見: 血液検查では, 白血球数 $7300 / \mathrm{mm}^{3}, \mathrm{CRP}$ $4.3 \mathrm{mg} / \mathrm{dl}$ と軽度の炎症所見を認めたが，他は特に異常 

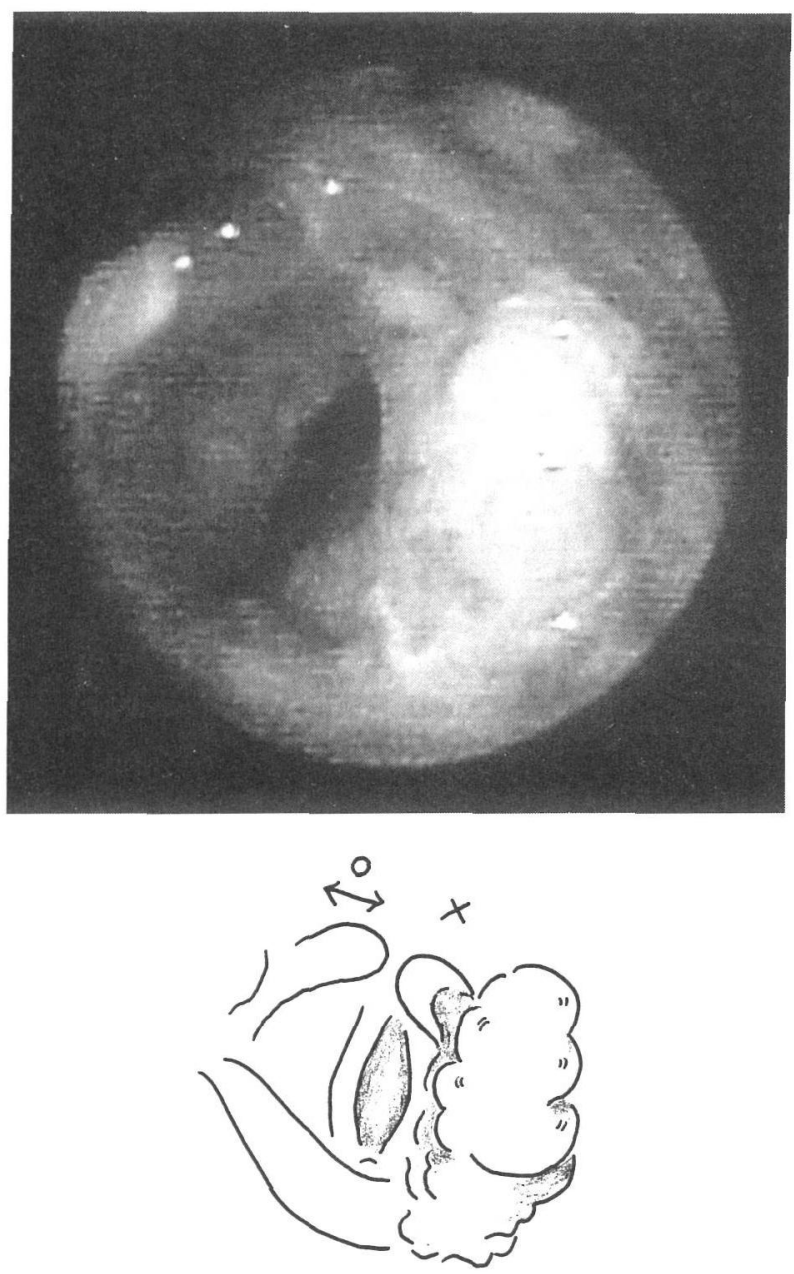

図 1 喉頭所見(初診時)

左披裂部に表面平滑な水疮状腫瘤を認め，左喉頭麻痺も 合併している。

を認めなかった。な和、ツベルクリン反応は陰性であっ た。喉頭単純X線所見では，喉頭左側の腫脹を認め，食 道透視では左梨状陷凹にバリウムの貯留を認めた(図 2 )。CT所見では，左披裂部に辺縁不整，内部不均一 な腫瘤性陰影を認めた(図 3 ).

病理組織所見：喉頭腫瘤からの病理組織標本は HE 染色で非常に強い血管炎と大小の細胞を認めた。大型の 細胞はビィンチン染色にて染まることから，肉芽系の細 胞であり，小型の細胞はUCHL 染色にて染まることか ら，Tリン八球と判明した(図 4)。乙かし，組織の同定 は非常に困難で，他さまざまな特殊染色を行うも悪性所 見は認めなかった。(な打血管炎が強いことより，ウェ ゲナ一肉芽腫症も疑い, 上気道病変队腎病変, 抗一好中

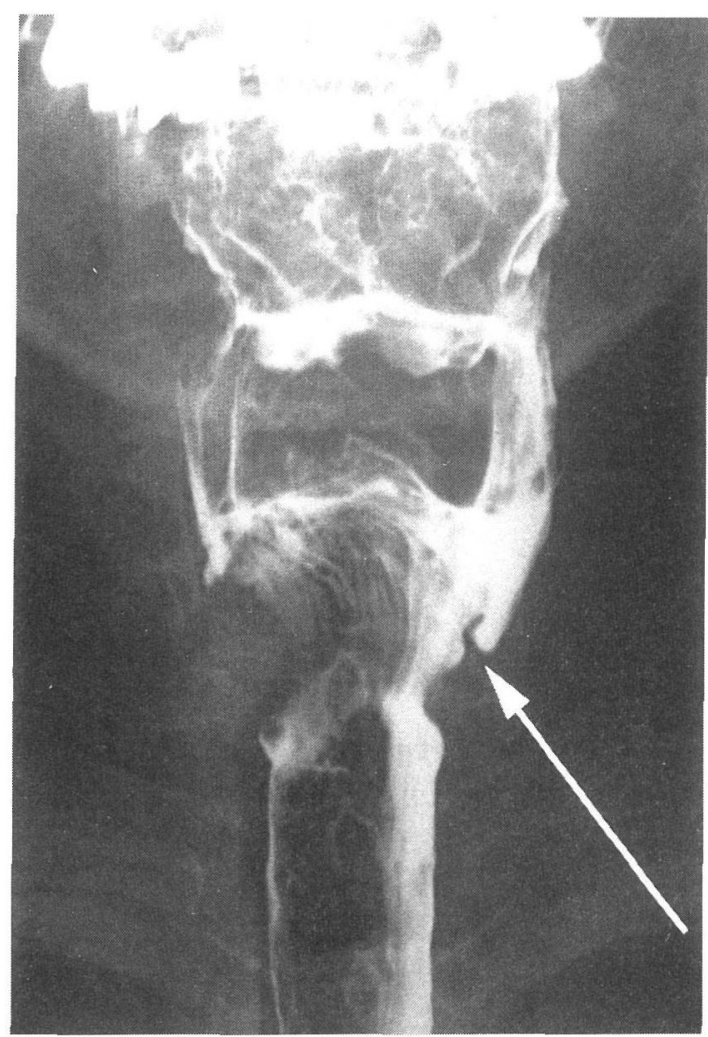

図 2 食道透視

左梨状陥凹にバリウムの貯留を認める(知).

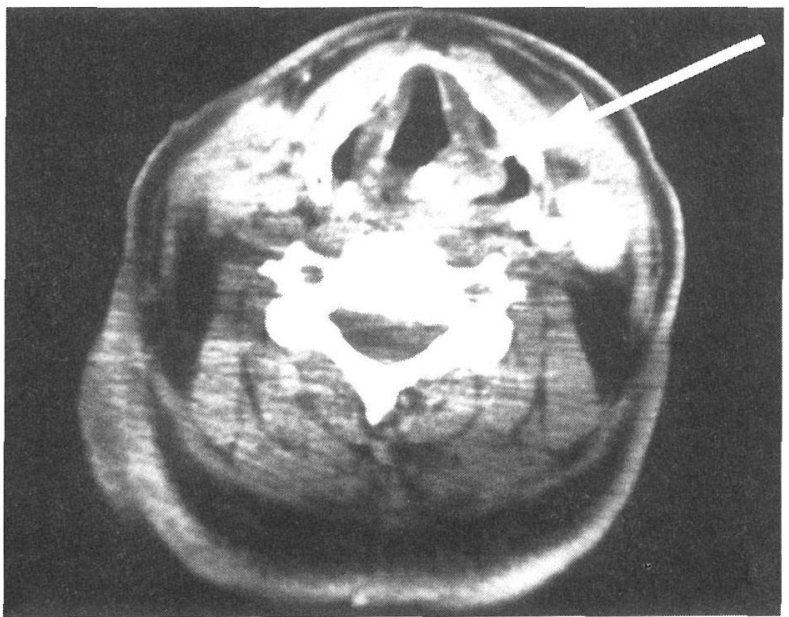

図 3 CT 所見

左披裂部に辺縁不整，内部不均一な腫瘤性陰影を認める (矢印).

球細胞質抗体 (C-ANCA) などの検査も行うも特に異常 は認めなかった.） 

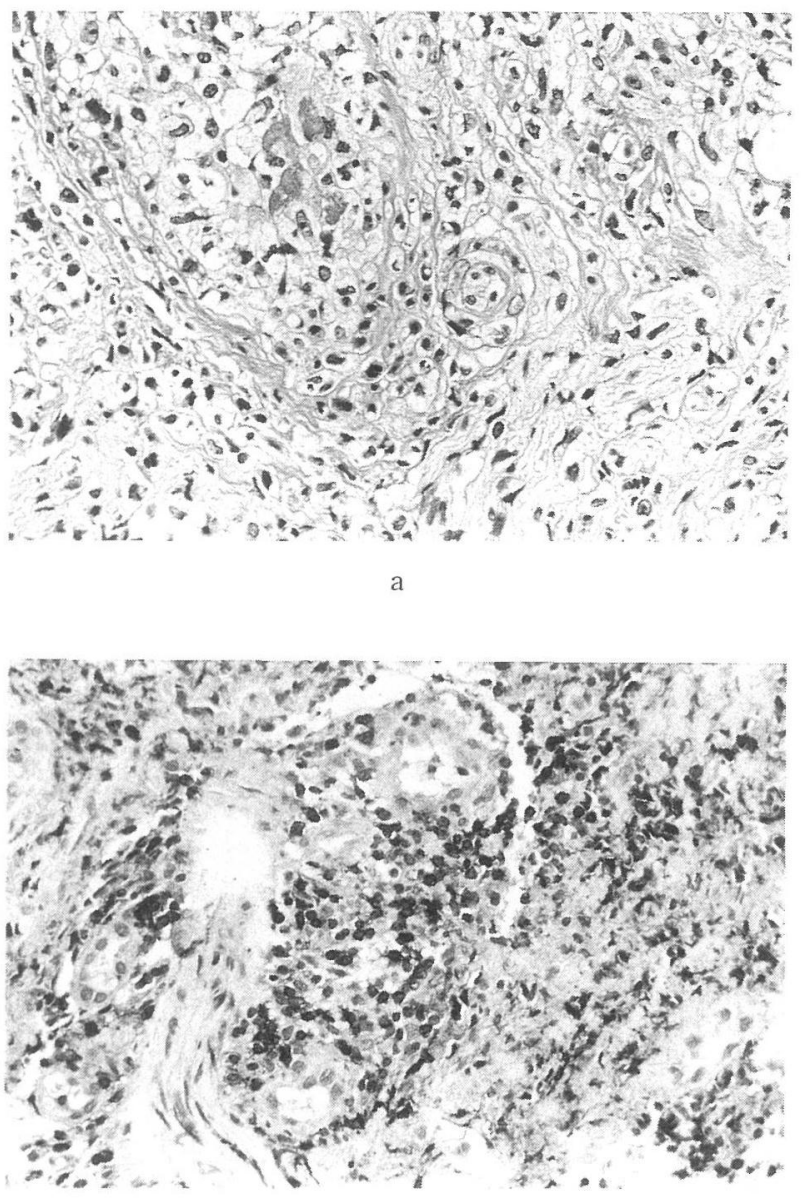

入院後 5 日目より左軟口蓋麻痺执よび難治性の吃逆が 出現したため, 頸静脈孔付近の病変を疑い頭蓋底 MRI を撮像したが，舌咽・迷走神経部分に軽度の高輝度像を 認める他には特に異常は認めなかった（図 5 )。（なお， 同側の椎骨動脈周团の高信号については血管造影など精 查を行らも原因不明であった，画像的には血管炎に合致 する所見であり，ウイルス感染による可能性も否定でき ない）ウイルス性疾患も考慮して，抗体価を測定してみ たところ，水痘一帯状へルペスの抗体価(CF：補体結合 反応)が128倍と高值を示した(表 1 ).ささらに，営光抗体 法で調ベてみると320倍でも陽性反応を示した（図６）。 ちなみに，髄液所見では細胞数の軽度增加を認めたが， 多発性硬化症で認められるオリゴクローナルバンドも陰 性であった。髄液中の水痘一带状へルペス抗体価 (CF 值)

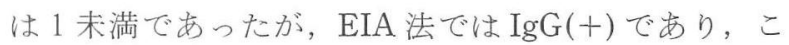
のことは初感染ではなく, 感染の既往がある, といらこ

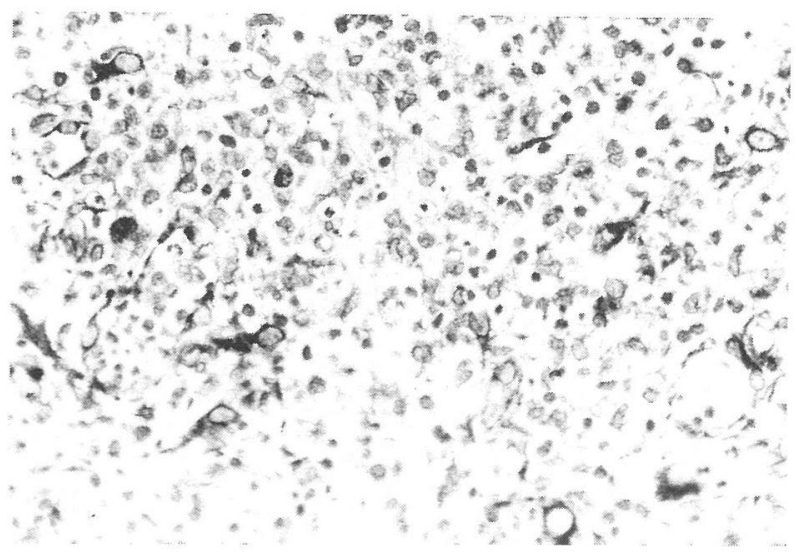

b

a HE 染色 $(\times 400)$

血管壁にリンパ球などの浸潤・増生を認め血管炎の所見で ある。

b ビメンチン染色 $(\times 400)$

大型の細胞が染まっており，肉芽系の細胞と判明

c UCHL 染色 $(\times 400)$

小型の細胞が染まって挆り，「リンパ球と判明

図 4 病理組織標本

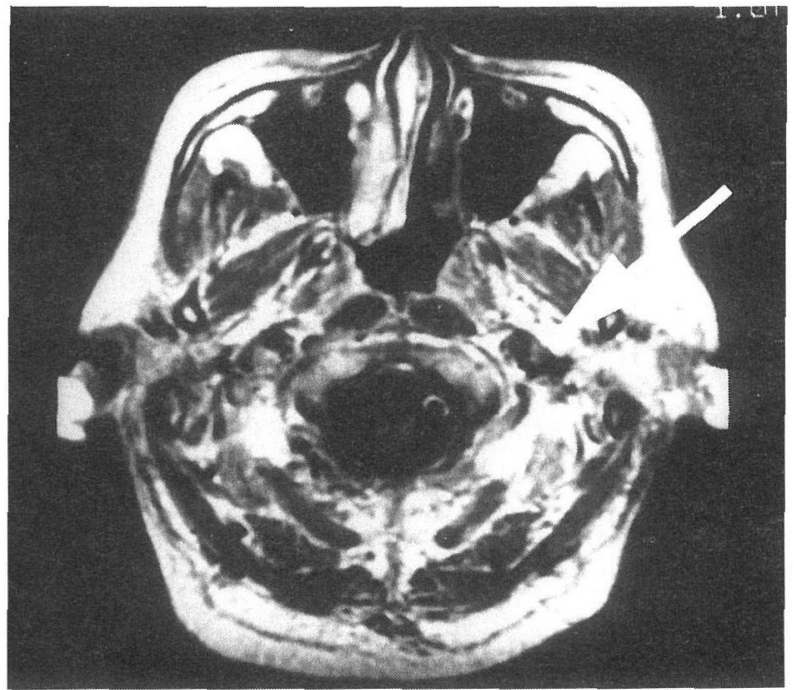

図 5 MRI 所見

舌咽・迷走神経部分に軽度の高輝度像を認める (知印). 
表 1 血清ウイルス抗体価

(単位; 倍)

\begin{tabular}{|c|c|c|c|}
\hline & $\begin{array}{c}\text { 11月27日 } \\
\text { (発症24日目) }\end{array}$ & $\begin{array}{c}\text { 12月11日 } \\
\text { (発症38日目) }\end{array}$ & $\begin{array}{c}\text { 平成 } 8 \text { 年 } 3 \text { 月18日 } \\
(\text { 発症136日目) }\end{array}$ \\
\hline 水痘一带状へルペス (CF) & 128以上 & 64 & 32 \\
\hline 単純へルペス $(\mathrm{CF})$ & 32 & 32 & 32 \\
\hline EB-VCA IgM & 10 未満 & 10未満 & \\
\hline EB-VCA IgG & 20 & 20 & \\
\hline サイトメガロ (CF) & 4 末満 & 4 末満 & \\
\hline インフルェンザ $\mathrm{A}(\mathrm{CF})$ & & 4 未満 & \\
\hline インフルエンザ B (CF) & & 4 未満 & \\
\hline
\end{tabular}

( CF : 補体結合反応)

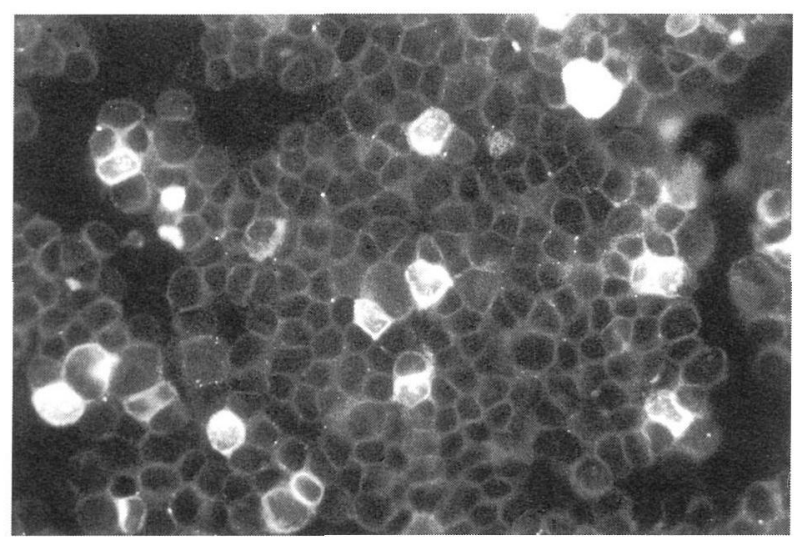

図 6 蛍光抗体法 $\times 320$ 倍 $(24$ 病日目)

(間接法)

標的細胞としてはサルの腎細胞を用い，感染力価として tissue culture infectious dose $10^{6} \sim 10^{7}$ 個 $/ \mathrm{ml}$ で測定し た.

\section{とを示唆している.}

症状ならびに治療経過(図 7)：入院当初は炎症所見が 認められたため抗生剤执よびステロイドの点滴治療を行 った。また，神経麻痺の改善が認められないため，ビタ ミンの投与およびステロイドの漸減療法も施行した。 入 院後 5 日目より出現した難治性の吃逆に対してクロナゼ パムの投与を行った。 2 週目より次第に喉頭腫瘤は消失 し，軟口蓋麻㿁执よび燕下障害も3 週目に改善した。 入 院後30日目であったが, 残存する喉頭麻㽻の改善を期待 して，抗ウイルス剤の投与も行い，38日目に退院となっ た。 た, 并の後のウイルス抗体価の推移は, 図 8 に示 寸よ5に平成 8 年 3 月 18 日 (136病日)には，32倍に低下 している.
な抏，平成 8 年 4 月 15 日現在，左喉頭麻痺は依然認め るものの, 初診時に認められた水疱状腫瘤は存在せず(図 9), 3 回目の生検 (70病日目)でも瘢痕組織のみであっ た，現在ビタミン剤の投与を行いながら，経過観察中で ある。

\section{考察}

喉頭麻痺の原因には様々なものがあるが，廣瀬1によよ ると特発性つまり原因不明のものが $2.3 \%$ ～ $58.0 \%$ を占 める。そ兵の中でも，ウイルスとの関連が以下の文献で示 唆されている。佐藤ら ${ }^{2)}$, 石井ら ${ }^{3)}$ にると疫学的調査

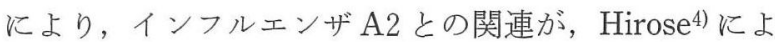
ると 30 症例中約半数に水痘帯状へルペスに対する血清学 的陽性反応を得たとしている。

しかし，実際にはウイルス感染の確定診断のためには ペア血清抗体価の測定や生検組織の DNA in situ hybridizationなどが必要であり，病初期での診察が必ずしも 容易でないために，実際の日常䛦療では困難なことが多 い.

本症例では，水疱病変から採取した粘膜組織に上皮細 胞が含まれなかったためか，DNA in situ hybridization では陰性であり，ウイルス感染の確定診断には至らなか った。（ちなみにプローブとして水痘一帯状疱疹ウイルス DNAEcoRI-B， H 断片のビオチン化したものを用い， hybridization の時間は室温で10分といら北里大学衛生 科学検査研究センターの方法に基づいて行った5). ) し かし，血清ウイルス抗体価の上昇(128倍) は健常人の抗 体価(図10）古からも明らかに高值であるとい劣る。また， 喉頭麻痺症状以外にも, 軟口蓋麻痹执よび吃逆といら迷 走神経症状が出現し, 悪性腫瘍による症状より, ウイル 


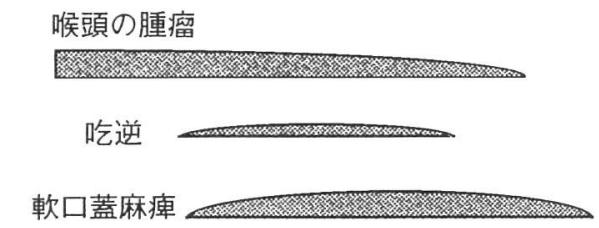

蒸下障害

\section{左喉頭麻㾝}

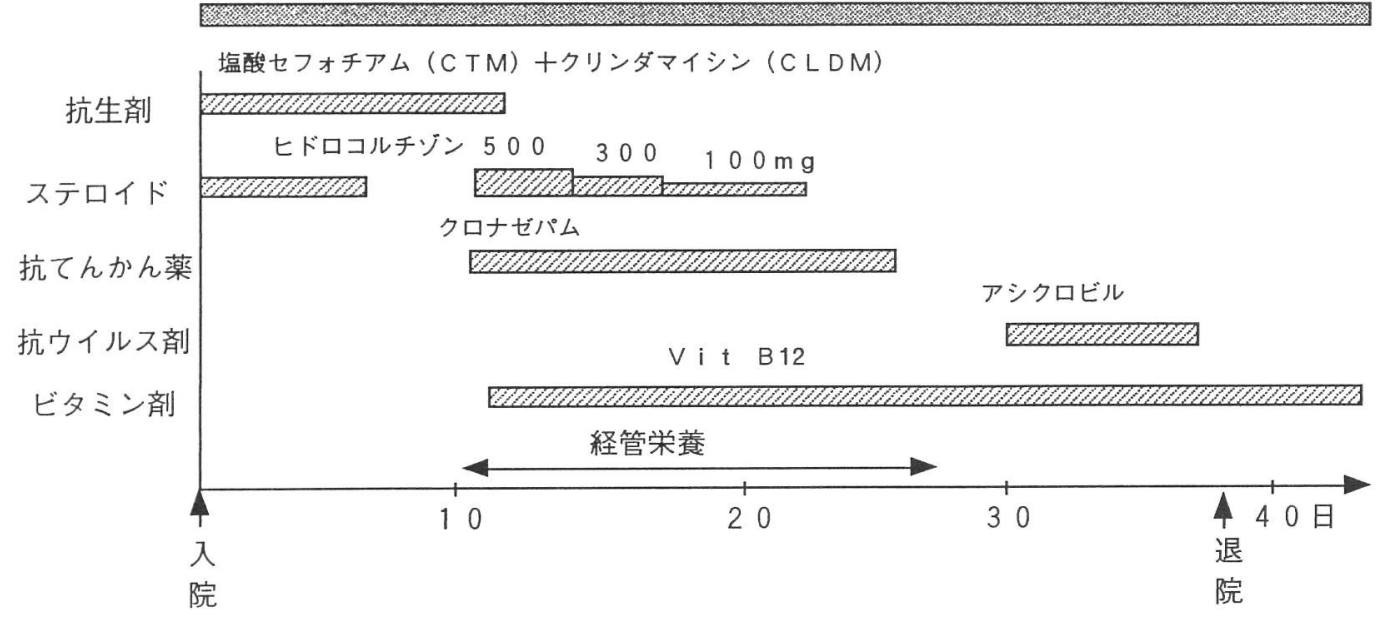

図 7 症状と治療経過

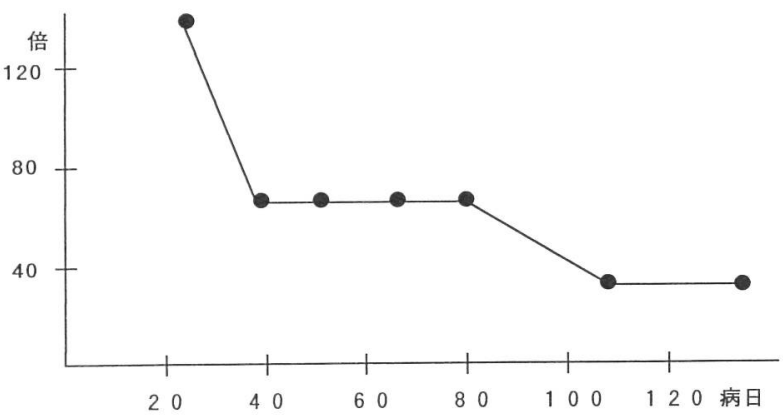

図 8 水痘-帯状へルペス抗体価(CF 值)の推移

スなどによる多発性神経炎の症状を呈したこと，考光う る原因疾患について全て除外し得たことなどから，水痘 一帯状へルペスによるウイルス性疾患と診断してょいと 思われる、ちなみにこの感染が初感染か否かについて， (患者の記憶では) 水痘感染の既往があり, また䯣液中の $\operatorname{IgG}(+), C F<1$ 未満上り潜伏感染の再活性化と思われ る。（な扮，患者は平成 7 年 11 月 3 日上り転勤で単身赴 任となり，そのストレスも一因と考光られる。）

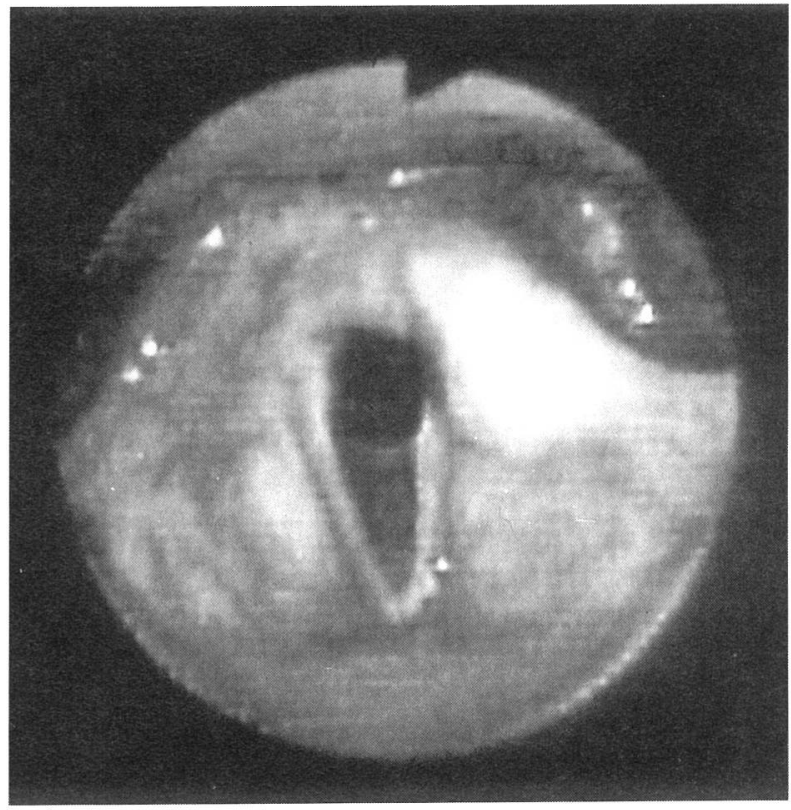

図 9 喉頭所見(164病日目) 左喉頭麻疩の久認める(な拉, 左披裂部の腫脹は計 3 回 そわたる生検後の疲痕によるものである)。

な扮，吃逆の病態・原因についてはいまだ確立したも 


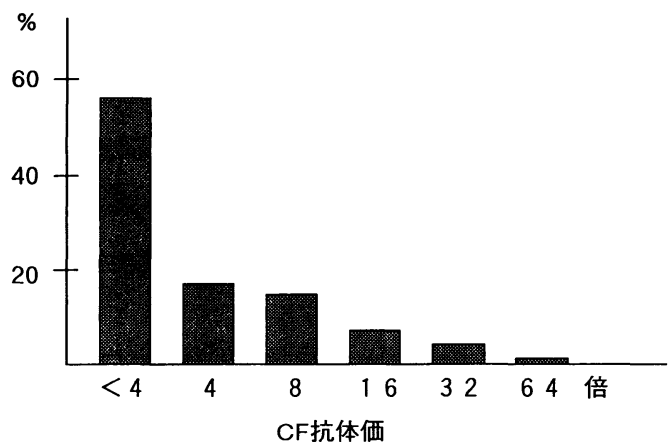

図10 健常人 (40歳以上) の varicella zoster virus (VZV) 抗体価 保有率

（田島マサ子，他：19906) より改変）

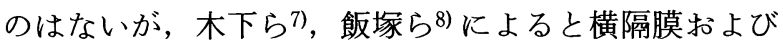
呼吸補助筋のミオクローヌスと考光られて叔り, 普段は 抑制されている原始反射とされている. 原因は, 中枢性 と末梢性があり, 中枢性の場合は上位(延䯣の呼吸中枢 の近傍) からの反射弓への抑制の消失, 末梢性では求心 路（迷走神経など)の刺激によるとされている。（なお， 本症例では, MRIにて舌咽・迷走神経部分に造影効果 を認めることより，末梢性ではないかと思われる.)なお， 軟口蓋の運動については口蓋帆張筋, 口蓋帆挙筋, 口蓋 舌笳, 口蓋咽頭筋などが関与しており9)10), 神経支配と しても三叉神経, 舌咽神経, 迷走神経, 交感神経などと 複雑である. が廣瀬9), 豊田ら ${ }^{11)}$ によと軟口蓋の運動 を支配する主な神経の起源は迷走神経由来で運動核は疑 核にあると考えられている，ちなみに，本症例では舌根 部の味覚正常 $(\mathbb{X})$ で, 胸鎖乳突筋の萎縮 $(X I)$, 舌の偏 位 (XII) など迷走神経以外の脳神経麻痺症状は認められ なかった。

また，混合性喉頭麻痺といら面からみると V〜 XII脳 神経麻痺が報告されているが, 本症例のように喉頭粘膜 の水疱性腫瘤を伴った例は非常に少ない。これは廣瀬1) によると恐らく発疹が水疱状を呈している時期が極めて 短時間で，じきに消えて黄白色の斑点に変わるためであ ろらとされている。また, Hunt ${ }^{12)}$ は咽頭部の粘膜のへ ルペスは何の痛みも不快感も起こさず，そのため見逃さ れてしまうと彼の症例18の中で述べている.

今までの特発性とされていたものの中には恐らくこの よらな症例もあり, 早期診断治療のためには, ウイルス 抗体価のより迅速な測定もしくは DNA in situ hybridizationなどの一般化が望まれる。

$$
\text { まとめ }
$$

61歳の男性の症例で, 初診時に喉頭腫瘤および左喉頭 麻痺を認め, CT, MRI からも悪性腫瘍を疑い, 精査を 行うも確定診断は出来なかった. 次第に, 他の迷走神経 麻痺症状が出現し, 頸静脈孔症候群も疑ったが, 最終的 には水痘一帯状へルペス感染による迷走神経障害と判明 した. 現在, 喉頭腫瘤は消失し, その他の症状も改善し たものの，喉頭麻痺のみ残存している.

本論文の要旨は, 第58回耳鼻咽喉科臨床学会学術講演会 (平 成 8 年 6 月 29 日, 名古屋)にて口演した。稿を終えるにあたり, 診断に御協力頂いた当院神経内科渡辺俊之先生, 脳神経外科山 本一夫先生に深く感謝いたします.

\section{参考文献}

1) 廣瀬 肇：混合性喉頭麻痺. 喉頭麻痺, 基礎と臨床(廣瀬 肇, 石井英男編). 218頁, 文光堂, 東京, 1992 .

2 ) 佐藤意生, 山田倫久, 平野 実: 特発性反回神経麻瘏とイ ンフルエンザ流行. 日耳鼻 $84: 601 \sim 606,1981$.

3 ) 石井英男, 武藤二郎, 亀井民雄, 他: 炎症性喉頭麻痺. 日 耳鼻 $74: 1562 \sim 1571,1971$.

4 ) Hirose $\mathrm{H}$ : Clinical observations on 750 cases of laryngeal palsy. Ann Bull RILP $15:$ 173 180, 1981.

5 ) 高橋慎一, 和山行正 : ビオチン化水痘 一帯状疮疹ウイル ス (VZV) DNA を用いた In Situ Hybridization 法による帯 状疮疹皮疹部塗抹標本の VZV DNA の検出一. 感染症誌 $64: 1367 \sim 1371,1990$.

6 ) 田島マサ子, 武田史子, 安田和人, 他: 高跲者に括ける一 ルペス科ウイルスの抗体調査. 臨床とウイルス $18: 369$ $375,1990$.

7 ) 木下彩栄, 秋口一郎, 木村 淳: 難治性吃逆を呈した多発 性硬化症の 1 例. 神経内科 $35: 348 \sim 349,1991$.

8 ）飯塚 統, 犬塚 貴, 岡本浩一郎, 他 : 難治性吃逆を主訴 とした多発性硬化症. 神経内科 $42: 273 \sim 275,1995$.

9 ) 廣瀬 肇：軟口蓋麻痺とその検査. JOHNS $8: 235 \sim 240$, 1992.

10）牛嶋達次郎：軟口蓋運動異常. JOHNS $7: 1030 \sim 1036$, 1991.

11）豊田健司, 橘 正芳: 軟口蓋麻痺の16例. 耳鼻臨床 79 : 421 426, 1986.

12) Hunt JR : The symptom-complex of the acute posterior poliomyelitis of the geniculate, auditory, glossopharyngeal and pneumogastric ganglia. Arch Int Med $5: 631 \sim 675$, 1910 .

$$
\left(\begin{array}{l}
\text { 原稿受付: 平成 } 9 \text { 年 } 3 \text { 月 } 28 \text { 日 } \\
\text { 原稿採択 : 平成 } 9 \text { 年 } 6 \text { 月 } 25 \text { 日 } \\
\text { 別刷請求先 : 田浦晶子 } \\
\text { ₹ } 520 \text { 大津市長等1-1-35 } \\
\text { 大津赤十字病院耳鼻咽喉科 }
\end{array}\right)
$$

